GM Crops

\title{
Genetic engineering in Cowpea (Vigna unguiculata): History, status and prospects
}

\section{Cristiane T. Citadin, Abdulrazak B. Ibrahim \& Francisco J. L. Aragão}

To cite this article: Cristiane T. Citadin, Abdulrazak B. Ibrahim \& Francisco J. L. Aragão (2011) Genetic engineering in Cowpea (Vigna unguiculata): History, status and prospects, GM Crops, 2:3, 144-149

To link to this article: https://doi.org/10.4161/gmcr.2.3.18069

曲 Published online: 30 Nov 2011.

Submit your article to this journal $\pi$

Џlll Article views: 319

Citing articles: 5 View citing articles 4 


\title{
Genetic engineering in cowpea (Vigna unguiculata) History, status and prospects
}

\author{
Cristiane T. Citadin, ${ }^{1,2}$ Abdulrazak B. Ibrahim ${ }^{1-3}$ and Francisco J.L. Aragão ${ }^{1,2, *}$
}

\begin{abstract}
'Embrapa Recursos Genéticos e Biotecnologia; ${ }^{2}$ Programa de Pós-graduação em Biologia Molecular; Departamento de Biologia Celular; Universidade de Brasilia; Brasília, Brazil; ${ }^{3}$ Department of Biochemistry; Ahmadu Bello University; Zaria, Nigeria
\end{abstract}

Keywords: cowpea, genetic transformation, agronomic traits, mendelian segregation

In the last three decades, a number of attempts have been made to develop reproducible protocols for generating transgenic cowpea that permit the expression of genes of agronomic importance. Pioneer works focused on the development of such systems vis-à-vis an in vitro culture system that would guarantee de novo regeneration of transgenic cowpea arising from cells amenable to one form of gene delivery system or another, but any such system has eluded researchers over the years. Despite this apparent failure, significant progress has been made in generating transgenic cowpea, bringing researchers much nearer to their goal than 30 years ago. Now, various researchers have successfully established transgenic procedures for cowpea with evidence of inherent transgenes of interest, effected by progenies in a Mendelian fashion. New opportunities have thus emerged to optimize existing protocols and devise new strategies to ensure the development of transgenic cowpea with desirable agronomic traits. This review chronicles the important milestones in the past 30 years that have marked the evolution of genetic engineering of cowpea. It also highlights the progress made and describes new strategies that have arisen, culminating in the current status of transgenic technologies for cowpea.

\section{Introduction}

Cowpea (Vigna unguiculata L. Walp.) is one of the most important and widely cultivated legumes in many parts of the world, particularly in Africa, Europe, Latin America and some parts of Asia and the United States (www.faostat.fao.org/faostat; http:// old.iita.org/).

Data available from the Food and Agriculture Organization (FAO) show that approximately 4 million tons of dry cowpea grains are produced annually in an area covering about 10 million hectares worldwide (www.faostat.fao.org/faostat). However, these numbers are actually underestimated because they do not include data from Brazil, India and some other countries. ${ }^{1}$ This

*Correspondence to: Francisco J.L. Aragão; Email: aragao@cenargen. embrapa.br

Submitted: 08/18/11; Revised: 09/09/11; Accepted: 09/13/11

http://dx.doi.org/10.4161/gmcr.2.3.18069 underestimation is even more apparent when we consider the fact that in Central America and East and Southern Africa, where common bean (Phaseolus vulgaris) in addition to Vigna unguiculata is grown and statistics from both crops are often mixed up. ${ }^{2}$ In Brazil, about 482,000 tons of the crop is produced in an area covering about 1.25 million hectares.

The cowpea grain represents a very important source of carbohydrates, lipids, minerals and vitamins, including folate, thiamin and riboflavin. ${ }^{3}$ It is well adapted to dry areas because of its tolerance to water scarcity and, when grown under the right conditions, the crop presents high productivity. These advantages make it a crop of choice for many farmers, who often cannot afford the investment required in managing other crops. ${ }^{4}$

Although considerable progress has been made in cowpea breeding leading to the development and introduction of several improved varieties in over 63 countries, a number of agronomic traits are still unavailable (http://old.iita.org/). For example, the development of Maruca vitrata resistant cowpea via traditional breeding has faced great challenges, requiring biotechnology based approach. Transgenic technologies therefore represent important avenues for the development of cowpea with desirable and improved traits.

In this review, we discuss the efforts and the success recorded so far in the global attempt to generate transgenic cowpea in order to meet the challenging demand for improving the crop through different transgenic approaches, spanning a period of three decades. We also report on the application of these protocols in generating transgenic cowpea with improved agronomic traits in a number of research works and some ongoing research projects, giving the current status and future prospects for the development of genetically engineered cowpea.

\section{Genetic Transformation}

In the last three decades, a number of attempts have been made to generate transgenic cowpea. ${ }^{5-8}$ The general approach in most cases has been through the employment of Agrobacterium tumefaciens as a gene delivery system via tissue culture (Fig. 1). By manipulating different factors such as target tissues, reporter genes, selection regimes, culture conditions and gene delivery system, researchers from different countries have been 


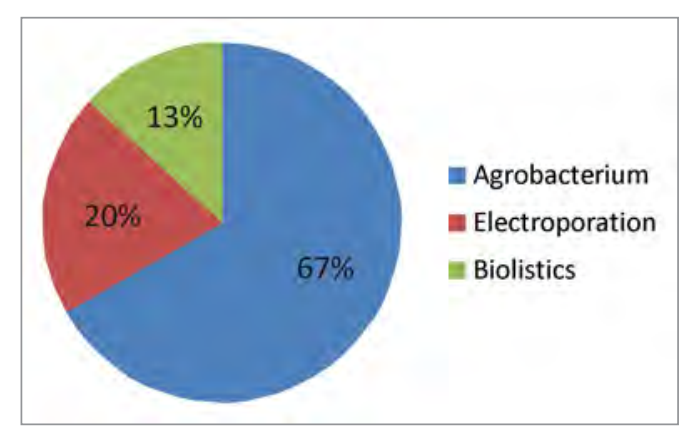

Figure 1. Distribution of the gene delivery system in the production of transgenic cowpea from 1987 to 2010.

engaged in generating transgenic cowpea with the ultimate aim of integrating genes of interest and their segregation in progenies arising from one generation to another in a Mendelian fashion (Table 1). In all of these approaches, one important aspect has been the establishment of in vitro propagation techniques capable of generating amenable culture that could produce totipotent cells with the potential to regenerate complete plants following gene delivery. Unfortunately, cowpea appeared to be recalcitrant to most in vitro manipulations, particularly via de novo regeneration. ${ }^{20}$ While researchers have been rushing to break this totipotency jinx in the bid to establish de novo regeneration and genetic transformation protocols since the late seventies, no such breakthrough has been recorded so far. However, with the development of novel strategies that do not necessarily rely directly on the use de novo regeneration systems, these problems appear to have been circumvented, with reports of some success stories. . $^{811,12,15}$

The first of such reports appeared in 1986, when Garcia et al. transformed leaf discs from primary leaves of cowpea using $A$. tumefaciens designed with a Ti plasmid harboring two identical chimeric genes for kanamycin resistance. The group obtained transgenic callus expressing nopaline synthase and amino glycoside phosphotraferase confirmed by DNA gel blot analysis. Following this, the same group used the protocol to express a viral RNA fragment (M-RNA) of Cowpea Mosaic Virus (CPMV) in callus of cowpea. ${ }^{6}$ The rationale behind this second strategy was to study the virus using two different constructs; one containing $35 \mathrm{~S}$ promoter of the Cauliflower Mosaic Virus $(\mathrm{CaMV})$ and the other harboring nopaline synthase promoter of $A$. tumefaciens, to ensure elimination of possible escapes. This approach resulted in a 10 -fold increase in the number of transcripts of the transgene using $35 \mathrm{~S} \mathrm{CaMV}$ promoter rather than nopaline synthase, leading to increased efficiency and thus applicability of the promoter in the transformation of cowpea. ${ }^{6}$ Indeed, the work underscored the possibility of studying cowpea parasites using this approach because of its applicability in different plant tissues. More importantly, it demonstrated for the first time that $A$. tumefaciens could be used as an exogenous gene delivery system on the one hand, and as means of studying virus associated with cowpea on the other. Although the vast majority of transformation experiments in the period between this report and 2010 have relied heavily on the Agrobacterium mediated system of gene delivery, a few other experiments have used direct systems of gene delivery (Fig. 1).

Despite the pioneering work of Garcia et al., ${ }^{5,6}$ and a number of other attempts to develop transformation and regeneration systems, ${ }^{7,9,10,21,22}$ it took close to a decade to produce the first transgenic cowpea plants when Muthukumar et al. co-cultured explants of cotyledons with disarmed $A$. tumefaciens expressing the gene for resistance against hygromicin, which were subjected to organogenesis leading to the generation of transgenic shoots. ${ }^{11}$ Analysis of data from the work showed that one third of the total shoots arising from co-cultured explants thrived well after acclimatization in soil following rooting. Although a good number of these plants attained maturity, seeds arising therefrom could not germinate. $^{11}$

It was another decade before any progress was made in cowpea transformation, when Ikea et al. reported on the production of the first transgenic cowpea via particle bombardment with evidence of molecular integration of the gene observed in T1, T2 and $T_{3}$ generations. In the experiment, meristematic tissues were pre-cultured 24 to $48 \mathrm{hrs}$ before bombardment with a plasmid containing the reporter gene gus along with the selectable marker bar under control of CaMV $35 \mathrm{~S}$ promoter. Although less than one percent of total explants bombarded were recovered and even fewer progenies expressing the transgenes were obtained, this work represented an important milestone in the historical trajectory of cowpea transformation. Indeed, it is a measure of this importance that the work reported for the first time transformation events from one generation to another, although the progenies generated did not fully obey the Mendelian law.

Three years later, the first report appeared in which stable transformation was successfully achieved and progenies were generated with Mendelian segregation. ${ }^{8}$ In a brilliant adoption of different strategies of transformation systems of legumes using $A$. tumefaciens, Popelka et al. ${ }^{8}$ were able to obtain transgenic cowpea plants with a transformation frequency of $0.15 \%$. Critical parameters exploited by the authors included use of cotyledon nodes of mature or developing seeds as explants and removal of auxins in the initial proliferative stage of the explants, with supplementation of low level of BAP during shoot formation and elongation as well as addition of thiol compounds during transfection and co-culture with Agrobacterium.

An improvement on this was recorded using an A. tumefaciens system in which a number of modifications were made, like the use of different cultivars, explant type, Agro strain and binary vector, co-culture medium and duration, type and application of selective agent and marker, and shoot and root induction media, ensuring higher frequency of transformation. ${ }^{13}$

Following this, our group developed an efficient cowpea transformation protocol which did not appear to be variety specific and presented a high frequency of transformants following Mendelian segregation. ${ }^{15}$ The system comprised of biolistic transformation of meristems using gus as a reporter and a novel selection regime based on the use of the herbicide imazapyr. This feat was achieved by introducing a mutant ahas gene in the vector used for transformation. The practicability of this approach, as well as the use of imazapyr, brought to the fore the enormous 
Table 1. The historical trajectory of the development of transgenic cowpea (Vigna unguiculata)

\begin{tabular}{|c|c|c|c|c|c|c|}
\hline $\begin{array}{l}\text { Gene of } \\
\text { intrest }\end{array}$ & $\begin{array}{l}\text { Selectable } \\
\text { marker }\end{array}$ & $\begin{array}{l}\text { Gene delivery } \\
\text { systems }\end{array}$ & Target tissue & $\begin{array}{l}\text { Transformation } \\
\text { effeciency }\end{array}$ & Degree of gene integration & Reference \\
\hline nptll & kanamycin & $A$ & Leaf discs & NR & Transgenic callus & 5 \\
\hline $\begin{array}{l}\text { CPMV } \\
\text { M-RNA }\end{array}$ & kanamycin & $A$ & Leaf discs & NR & Transgenic Callus & 6 \\
\hline gus & - & $A$ & Mature embryos & NR & Transgenic zygotic embryos & 7 \\
\hline gus & - & $E$ & Mature embryos & NR & Transgenic zygotic embryos & 9 \\
\hline gus & - & $E$ & Mature embryos & NR & Transgenic zygotic embryos & 10 \\
\hline hpt & hygromycin & $A$ & $\begin{array}{l}\text { Cotiledonary } \\
\text { explants }\end{array}$ & NR & Regenerated transgenic plants & 11 \\
\hline gus & phosphinothricin & B & $\begin{array}{l}\text { Meristematic } \\
\text { explants }\end{array}$ & NR & $\begin{array}{l}\text { Progenie transmission/not } \\
\text { Mendelian segregation }\end{array}$ & 12 \\
\hline gus & Phosphinothricin & $A$ & $\begin{array}{l}\text { Cotyledonary nodal } \\
\text { cuttings }\end{array}$ & $0.15 \%$ & $\begin{array}{l}\text { Transgenic plants with Mendelian } \\
\text { progenies transmission }\end{array}$ & 8 \\
\hline gus & kanamycin & $A$ & $\begin{array}{l}\text { Cotyledonary nodal } \\
\text { cuttings }\end{array}$ & $0.76 \%$ & $\begin{array}{l}\text { Transgenic plants with Mendelian } \\
\text { progenies transmission }\end{array}$ & 13 \\
\hline gus & geneticin & $A$ & $\begin{array}{l}\text { Cotiledonary nodal } \\
\text { cuttings }\end{array}$ & $1.64 \%$ & $\begin{array}{l}\text { Transgenic plants with Mendelian } \\
\text { progenies transmission }\end{array}$ & 14 \\
\hline gus & imazapyr & B & $\begin{array}{l}\text { Shoor apical } \\
\text { meristem }\end{array}$ & $0.9 \%$ & $\begin{array}{l}\text { Transgenic plants with Mendelian } \\
\text { progenies transmission }\end{array}$ & 15 \\
\hline$\alpha A l-1$ & geneticin & $A$ & $\begin{array}{l}\text { Cotiledonary nodal } \\
\text { cutting }\end{array}$ & $1.67 \%$ & $\begin{array}{l}\text { Transgenic plants with Mendelian } \\
\text { progenies transmission }\end{array}$ & 16 \\
\hline Cry1Ab & geneticin & $E$ & Nodal buds & NR & $\begin{array}{l}\text { Progenie transmission/not } \\
\text { Mendelian segregation }\end{array}$ & 17 \\
\hline gus & Phosphinotricin & $A$ & Embryos & $3.9 \%$ & $\begin{array}{l}\text { Progenie transmission/Mendelian } \\
\text { segregation was not reported }\end{array}$ & 18 \\
\hline gus & hygromycin & $A$ & $\begin{array}{l}\text { Cotiledonary nodal } \\
\text { cuttings }\end{array}$ & $1.61 \%$ & Transgenic plant regenerated & 19 \\
\hline
\end{tabular}

A, Agrobacterium tumefaciens; B, Biolistics; E, Electroporation; NR, Not reported; CPMV, cowpea mosaic virus; $\alpha A$ I-1, Alpha-amylase inhibitor-1.

potential of this system in producing transgenic cowpea that expresses traits of agronomic importance. Besides the relatively higher transformation frequency $(0.9 \%)$, the work demonstrated efficient gene transfer which was inherited by $\mathrm{T} 1$ and $\mathrm{T} 2$ generations with segregation according to Mendelian law.

\section{Agronomic Problems as a Target for Genetic Engineering}

Because of its great economic importance, cowpea has been the target of breeding programs for many years in different centers of research the world over (http://old.iita.org/). The ultimate goal of these programs is to address agronomic problems such as attack by virus, bacteria, pests and diseases. ${ }^{23,24}$ Unfortunately, the apparent unavailability of resistant genes in the plant has rendered the conventional breeding approach less attractive in strategies for producing pest-resistant genotypes of cowpea. This task is even more herculean given the cross-incompatibility between the cultivated and wild Vigna species that may possess some inherent resistance. ${ }^{25-27}$
At almost every stage of its development, cowpea is confronted by one form of biological stress or another (http://old.iita.org/). This includes attack by aphids like Aphis craccivora which invades leaves and stems of seedlings, extracting juice and infecting plants with cowpea mosaic virus at the same time. During flower formation, the crop is attacked by thrips like Megalurothrips sjostedt $i$ which prevents the formation of seeds. Bruchid weevils like Callosobruchus maculatus, on the other hand, destroy the seeds following harvest. Besides susceptibility to attack by fungi, bacteria, virus and some classes of nematodes, parasitic weeds also retard and sometimes completely prevent its growth (http://old. iita.org/). These factors often result in severe economic losses for farmers and lead to low yields which, in Africa, stand at $350 \mathrm{Kg}$ per hectare (http://old.iita.org/). For example, M. vitrata has been reported to cause a $17-53 \%$ yield loss in cowpea ${ }^{28}$ while C. maculatus causes $20-60 \%$ grain loss. ${ }^{29,30}$ In Brazil and several other Latin American countries, the most common causes of these losses are viruses, which are often transmitted by insects. Foremost among them are Cowpea Severe Mosaic Virus (CPSMV), Cowpea Aphid-Borne Mosaic Virus (CABMV) and 
Cowpea Golden Mosaic Virus (CPGMV). Collectively, these viruses cause losses of about $81 \% .^{16,31}$

The most obvious means of controlling these insects would appear to be the use of insecticides and other pesticides, but besides being expensive and therefore beyond the reach of the often poor farmers that grow the crop, these may pose serious hazards to users and the ecosystem. Unfortunately, even such imperfect solutions do not exist for combating viruses.

With the limitations encountered in breeding programs, biotechnology-based approaches seem to hold the key to effectively tackling these biological stresses. Genetic engineering offers important strategies with promising results in addressing not only problems caused by pests and diseases, but also by viruses. $^{20}$

\section{Introduction of Useful Agronomic Traits}

The first report on the regeneration and stable transformation of cowpea expressing a gene of agronomic importance appeared in 2008 when workers generated transgenic cowpea that expressed some degree of insect resistence. ${ }^{14}$ The establishment of an $A$. tumefaciens-mediated transformation protocol using geneticin and supplementation of post-selection media with benzyl aminopurine for over 3 weeks ensured a regeneration frequency of $1.64 \% .{ }^{32}$ The strategy employed was based on the use of the gene for $\alpha$-amylase inhibiting protein $(a A I-1)$ from $P$. vulgaris as a means of conferring resistance against different insects. The efficiency of transformation in this case was enhanced by using multiple copies of the gene vir, co-culture of explants in the presence of thiol compounds and by sequential selection using geneticin. ${ }^{14}$ The work reported up to $82.3 \%$ decrease in insect susceptibility in transgenic plants when subjected to Callosobruchus chinensis. ${ }^{14}$ Without doubt, this work represented an important breakthrough in the development of transgenic cowpea and paved the way for several attempts to optimize existing protocols and, in some cases, the development of novel strategies for pest and disease resistance in cowpea. ${ }^{19}$

This successful demonstration of cowpea resistance using aAI-1 gene was followed by the report of another considerable resistance against $M$. vitrata by $\mathrm{T}_{3}$ progenies after transformation of nodal cuttings with a plasmid harboring $C r y 1 A b$, the now popular gene for protein toxin from Bacillus thuringiensis, using nptII as a selectable marker under the control of $35 \mathrm{~S}$ of CaMV.$^{17}$ In an attempt to improve on this, Adesoye et al. ${ }^{18}$ employed vacuum infiltration of embryos in the transformation of cowpea and reported a fairly high degree of transformation frequency in T1 seeds ranging between $2.5 \%$ and $3.9 \%$.

Recently, researchers have reported the use of CrylAb gene from $B$. thuringiensis to produce several transgenic lines of cowpea with resistence against Helicoverpa armigera and $M$. vitrata. These Bt-cowpeas are being field tested in countries like Nigeria with good preliminary results. ${ }^{33}$ In addition, a number of field trials have been going on in the last couple of years using cowpea with high degree of resistance against $C$. maculatus in field trials in Puerto Rico and Nigeria with promising results (www.csiro. $\mathrm{au})$.
Based on the foregoing, it appears that transformation and regeneration protocols for the development of transgenic cowpea are well established. The focus now is employment of these techniques in concert with traditional breeding approaches for largescale production of elite varieties expressing genes of agronomic importance.

\section{What Needs to be Done}

Although we are far from resolving the problems associated with the cultivation and utilization of cowpea, the success recorded so far in the development and application of different transgenic technologies to address these problems are clear indicators that these goals are attainable within the next few years.

The success of Bt toxin recorded in several crops including cowpea, demonstrates the enormous benefits the crop stands to gain from transgenic technologies. However, with the possible emergence of insect resistance to Bt toxin, new control strategies involving a different mode of action like the use of RNA interference are emerging and promise to be valuable in managing the problems associated with the production of cowpea. ${ }^{34-37}$

Developed using the natural mechanism of gene regulation in eukaryotes, RNA-mediated gene silencing is of potentially great value thanks to its practicability and effectiveness. The system has been applied in silencing the expression of many target genes mediated by siRNA molecules. ${ }^{38,39}$

Early experiments using RNA gene silencing underscore the high potential of this approach in controlling insects as well as other threats to cowpea. It has been demonstrated that silencing of essential genes in insects mediated by siRNA may cause the cessation of feeding and even death of the insects. ${ }^{35-37}$ An endeavor that would develop transgenic cowpea which expresses some siRNA molecules whose sequences could trigger signals for silencing essential genes in insects, bacteria and virus, without compromising the cowpea or the consumer's health seems to be attractive. Indeed, this type of strategy has been applied in a number of crops and among the candidate genes used are insectvacuolar ATPase and tubulin. ${ }^{35-37}$

The development of genetically engineered common bean with RNAi-mediated resistance to Bean Golden Mosaic Virus ${ }^{40}$ opened the possibility of generating cowpea with resistance against the CPSMV using the RNAi strategy in our research group. Plants resulting from this experiment presented a high level of resistance against the virus in greenhouse tests (unpublished). The next phase is to carry out field tests.

Another important candidate gene of great potential in improving cowpea is cystatin, a cysteine proteinase inhibitor with potential as a pest resistance conferring agent. ${ }^{41-42}$ We are currently trying to develop transgenic cowpea expressing chicken cystatin with a view to expressing insecticidal activity against bruchids.

Although cowpea is an important source of nutrients, including several amino acids, it is deficient in sulfur-containing amino acids, a trait common in most legumes. Several strategies have been devised to address this using transgenic technology in a number of legumes. ${ }^{43,44}$ Our group is using a transgenic approach 
to introduce methionine-rich protein in cowpea using the gene for delta-zein from maize. ${ }^{45}$

In spite of its ability to thrive under harsh environmental conditions, the growing demand for cowpea necessitates the development of this legume with some improved resistance against herbicides. In line with this, we are using the protocol established in our laboratory ${ }^{15}$ to generate cowpea with resistance against the herbicide imazapyr (unpublished).

\section{Conclusion}

In the last few years, significant progress has been made to establish different protocols and their application in the development of transgenic cowpea with one type of characteristic or another. Through the participation of research centers from all over the world, there have been important findings that started with obtaining transgenic callus; from that came transgenic plants that exhibited Mendelian segregation, culminating in recent findings that have led to the production of transgenic cowpea with resistance against $C$. maculatus and $M$. vitrata as a result of the insertion of a gene of agronomic importance in the plant. Currently, various research groups in countries including Australia, Brazil, India and Nigeria possess wellestablished transformation systems which can be harnessed to improving cowpea, a hitherto unreachable goal by means of traditional breeding. Challenges posed by pests and disease can be tackled through systematic application and optimization of the protocols arising from the efforts of the last three decades.

There are plans for more trials of some of the insect resistant varieties developed, and with the possible emergence of new strategies to use RNA interference, as seen in the development of a genetically engineered common bean with RNAi-mediated resistance to Bean golden mosaic virus, ${ }^{40}$ there is likely to be even greater success and more breakthroughs in the development of elite transgenic cowpea.

\section{References}

1. Singh BB, Ehlers JD, Freire SB, Filho FR. Recent progress in cowpea breeding. In: Fatokun CA, Tarawali SA, Singh BB, Kormawa PM, Tamo M, (Eds). Challenges and Opportunities for Enhancing Sustainable Cowpea Production. Intl Inst Tropical Agric Ibadan, Nigeria 2002; 22-40.

2. Timko MP, Singh BB. Cowpea, a Multifunctional Legume. In Moore PH, Ming R, (Eds.) Genomics of Tropical Crop Plants Springer 2008; 227-58.

3. Nielsen SS, Brandt WE, Singh BB. Genetic variability for nutritional composition and cooking time of improved cowpea lines. Crop Sci 1993; 33:469-72; DOI: $10.2135 /$ cropsci1993.0011183X00330003001 $0 \mathrm{x}$.

4. Singh BB, Ajeigbe HA, Tarawali SA, FernandezRivera S, Abubakar M. Improving the production and utilization of cowpea as food and fodder. Field Crops Res 2003; 84:169-77; DOI:10.1016/S03784290(03)00148-5.

5. Garcia JA, Hille J, Goldbach R. Transformation of cowpea (Vigna unguiculata) cells with an antibiotic-resistance gene using a Ti-plasmid-derived vector. Plant Sci 1986; 44:37-46; DOI:10.1016/0168-9452(86)90166-

6. Garcia JA, Hille J, Vos P, Goldbach R. Transformation of cowpea (Vigna unguiculata) with a full-length DNA copy of cowpea mosaic virus M-RNA. Plant Sci 1987; 48:89-98; DOI:10.1016/0168-9452(87)90135-X

7. Penza R, Lurquin PF, Filippone E. Gene transfer by co-cultivation of mature embryos with Agrobacterium tumefaciens: application to cowpea (Vigna unguiculata L. Walp). J Plant Physiol 1991; 138:39-43.

8. Popelka JC, Gollasch S, Moore A, Molvig L, Higgins TJV. Genetic transformation of cowpea (Vigna unguiculata L.) and stable transmission of the transgenes to progeny. Plant Cell Rep 2006; 25:304-12; PMID:16244884; DOI:10.1007/s00299-005-0053-x.

9. Penza R, Akella V, Lurquin PF. Transient expression and histological localization of a gus chimeric gene after direct transfer to mature cowpea embryos. Biotechniques 1992; 13:576-80; PMID:1476727.

10. Akella V, Lurquin PF. Expression in cowpea seedlings of chimeric transgenes after electroporation into seedderived embryos. Plant Cell Rep 1993; 12:110-7; DOI:10.1007/BF00241945.
11. Muthukumar B, Mariamma M, Veluthambi K Gnanam A. Genetic transformation of cotyledon explants of cowpea (Vigna unguiculata L. Walp) using Agrobacterium tumefaciens. Plant Cell Rep 1996; 15:980-5.

12. Ikea J, Ingelbrecht I, Uwaifo A, Thotttappilly G. Stable gene transformation in cowpea (Vigna unguiculata L Walp.) using particle gun method. Afr J Biotechno 2003; 2:211-8.

13. Chaudhury D, Madanpotra S, Jaiwal R, Saini R, Kuma AP, Jaiwal PK. Agrobacterium tumefaciens-mediated high frequency genetic transformation of an Indian cowpea (Vigna unguiculata L. Walp.) cultivar and transmission of transgenes into progeny. Plant Sci 2007; 172:692-700; DOI:10.1016/j.plantsci.2006.11.009.

14. Solleti SK, Bakshi S, Purkayastha J, Panda SK, Sahoo L. Transgenic cowpea (Vigna unguiculata) seeds expressing a bean $\alpha$-amylase inhibitor 1 confers resistance to storage pests, bruchid beetles. Plant Cell Rep 2008; 27:1841-50; PMID:18784925; DOI:10.1007/s00299008-0606-x

15. Ivo NL, Nascimento CP, Vieira LS, Campos FAP, Aragão FJL. Biolistic-mediated genetic transformation of cowpea (Vigna unguiculata) and stable Mendelian inheritance of transgenes. Plant Cell Rep 2008; 27:1475-83; PMID:18587583; DOI:10.1007/s00299008-0573-2.

16. Umaharan P, Ariyanayagan RP, Haque SQ Resistance to cowpea severe mosaic virus, determined by three dosage dependent genes in Vigna unguiculata L. Walp. Euphytica 1997; 95:49-55, DOI:10.1023/A:1002988003402.

17. Adesoye A, Machuka J, Togun A. CRY $1 A B$ transgenic cowpea obtained by nodal electroporation. Afr Biotechnol 2008; 7:3200-10.

18. Adesoye A, Machuka J, Togun A. Transformation of cowpea (Vigna unguiculata L. Walp.) by Agrobacterium infiltration. Appl Biosci 2010; 30:1845-60.

19. Raveendar $S$, Ignacimuthu S. Improved Agrobacterium mediated transformation in cowpea Vigna unguiculata L. Walp. Asian J Plant Sci 2010; 9:256-63; DOI:10.3923/ajps.2010.256.263

20. Aragão FJL, Campos FAP. Common bean and cowpea. In: Pua EC, Davey MR, Eds. Biotechnology in agriculture and forestry. Transgenic crops IV. Berlin: Springe 2007; 263-76.

21. Perkins EJ, Stiff CM, Lurquin PF. Use of Alcaligenes eutrophus as a source of genes for 2,4-D resistance in plants. Weed Sci 1987; 35:12-8.

22. Filippone E. Genetic transformation of pea and cowpea by co-cultivation of tissues with Agrobacterium tumefaciens carrying binary vectors. In: Ng NQ, Monti LM, Eds. Cowpea genetic resources, contributions in cowpea exploration, evaluation and research from Italy and IITA. Ibadan-Nigeria: IITA 1990; 175-81.
23. Fatokun CA. Breeding cowpea for resistance to insect pests: attempted crosses between cowpea and Vigna vexillata. In: Fatokun CA, Tarawali SA, Singh BB, Kormawa PM, Tamo M, Eds. Challenges and opportunities for enhancing sustainable cowpea production. Ibadan-Nigeria: IITA 2000; 52-61.

24. Singh BB, Ehlers JD, Sharma B, Freire-Filho FR Recent progress in cowpea breeding. In: Fatokun CA, Tarawali SA, Singh BB, Kormawa PM, Tamò M, Eds. Challenges and opportunities for enhancing sustainable cowpea production. Ibadan-Nigeria: IITA 2000; 185 95.

25. Jackai LEN, Padulosi S, Ng Q. Resistance to the legume pod borer, Maruca vitrata Fabricius and the probable modalities involved in wild Vigna. Crop Prot 1996; 15:753-61; DOI:10.1016/S0261-2194(96)00050-6.

26. Sharma P, Sharma JD. Plants showing antiplasmodial activity from crude extracts to isolated compounds. Indian J Malariol 1998; 35:57-110; PMID:10448228.

27. Fatokun CA, Perrino P, Ng NQ. Wide crossing in African Vigna species. In: Singh BB, Mohan Raj DR, Dashiell KE, Jackai LEN, Eds. Advances in cowpea research. Ibadan-Nigeria: IITA 1997; 50-7.

28. Liao CT, Lin CS. Occurrence of the legume pod borer, Maruca testulalis Geyer (Lepidoptera: Pyralidae) on cowpea (Vigna unguiculata Walp) and its insecticides application trial. Plant Protection Bulletin 2000; 42:213-22.

29. Abrol DP. Pulse susceptibility to Callosobruchus chinen sis (L) (Bruchidae: Coleoptera) under field conditions. Trop Agric 1999; 76:150.

30. Tarver MR, Shade RE, Shukle RH, Moar WJ, Muir WM, Murdock LM, et al. Pyramiding of insecticidal compounds for control of the cowpea bruchid (Callosobruchus maculatus F.). Pest Manag Sci 2007; 63:440-6; PMID:17340671; DOI:10.1002/ps.1343.

31. Araújo JP, Rios GP, Watt EE, Neves BP, Fageria NK, Oliveira IP, et al. Cultura do Caupi, Vigna unguiculata (L.) Walp: descrição e recomendaçōes técnicas de cultivo. EMBRAPA Circular Técnica 1984; 18:82.

32. Solleti SK, Bakshi S, Sahoo L. Additional virulence genes in conjunction with efficient selection scheme, and compatible culture regime enhance recovery of stable transgenic plants in cowpea via Agrobacterium tumefaciens-mediated transformation. J Biotechnol 2008; 135:97-104; PMID:18394740; DOI:10.1016/j. jbiotec.2008.02.008.

33. Higgins TJV, Gollasch S, Molvig L, Moore A, Popelka C, Watkins P, et al. Genetic transformation of cowpea for protection against bruchids and caterpillars. Fifth World Cowpea Research Conference 2010; SallySenegal.

34. Gordon KH, Waterhouse PM, RNAi for insectproof plants. Nat Biotechnol 2007; 25:1231-2; PMID:17989682; DOI:10.1038/nbt1107-231. 
35. Baum JA, Bogaert T, Clinton W, Heck GR, Feldmann P, Ilagan $\mathrm{O}$, et al. Control of coleopteran insect pests through RNA interference. Nat Biotechnol 2007; 25:1322-6; PMID:17982443; DOI:10.1038/nbt1359.

36. Price DRG, Gatehouse JA. RNAi-mediated crop protection against insects. Trends Biotechnol 2008; 26:393-400; PMID:18501983; DOI:10.1016/j. tibtech.2008.04.004.

37. Upadhyay SK, Chandrashekar K, Thakur N, Verma PC, Borgio JF, Singh PK, et al. RNA interference for the control of whiteflies (Bemisia tabaci) by oral route. J Biosci 2011; 36:153-61; PMID:21451256, DOI:10.1007/s12038-011-9009-1.

38. Fire A, Xu SQ, Montgomery MK, Kostas SA, Driver SE, Mello CC. Potent and specific genetic interference by double-stranded RNA in Caenorhabditis elegans. Nature 1998; 391:806-11; PMID:9486653; DOI: $10.1038 / 35888$

39. Ghildiyal M, Zamore PD. Small silencing RNAs: an expanding universe. Nat Rev Genet 2009; 10:94-108; PMID:19148191; DOI:10.1038/nrg2504.

40. Bonfim K, Faria JC, Nogueira E, Mendes E, Aragão FJ. RNAi-mediated resistance to Bean golden mosaic virus in genetically engineered common bean (Phaseolu vulgaris). Mol Plant Microbe Interact 2007; 20:717-26; PMID:17555279; DOI:10.1094/MPMI-20-6-0717.
41. Aguiar JM, Franco OL, Rigden DJ, Bloch JRC Monteiro ACS, Flores VMQ, et al. Molecular modeling and inhibitory activity of cowpea cystatin against bean bruchid Pests. Proteins 2006; 63:662-70 PMID:16470583; DOI:10.1002/prot.20901.

42. Martinez M, Diaz I. The origin and evolution of plant cystatins and their target cysteine proteinases indicate a complex functional relationship. BMC Evol Biol 2008; 8:198; PMID:18616807; DOI:10.1186/1471-2148-8198.

43. Tu HM, Godfrey LW, Sun SS. Expression of the Brazil nut methionine-rich protein and mutants with increased methionine in transgenic potato. Plant Mol Biol 1998; 37:829-38; PMID:9678578; DOI:10.1023/A:1006098524887.

44. Marcellino LH, Neshich G, Sá MF, Krebbers E, Gander E. Modified $2 \mathrm{~S}$ albumins with improved tryptophan content are correctly expressed in transgenic tobacco plants. FEBS Lett 1996; 385:154-8; PMID:8647241; DOI:10.1016/0014-5793(96)00375-4
45. Alexandrov NN, Brover VV, Freidin S, Troukhan ME, Tatarinova TV, Zhang $\mathrm{H}$, et al. Insights into corn genes derived from large-scale cDNA sequencing. Plant Mol Biol 2009; 69:179-94; PMID:18937034; DOI: $10.1007 / s 11103-008-9415-4$.

46. Gatehouse JA. Biotechnological prospects for engineering insect-resistant. Plant Physiol 2008; 146:881-7; PMID:18316644; DOI:10.1104/pp.107.111096.

47. Huvenne H, Smagghe G. Mechanisms of dsRNA uptake in insects and potential of RNAi for pest control: A review. J Insect Physiol 2010; 56:22735; PMID:19837076; DOI:10.1016/j.jinsphys.2009.10.004.

48. Àlvarez-Alfageme F, Martinez M, Pascual-Ruiz S, Castañera P, Diaz I, Ortego F. Effects of potato plants expressing a barley cystatin on the predatory bug Podisus maculiventris via herbivorous prey feeding on the plant. Transgenic Res 2007; 16:1-13, PMID:17072562; DOI:10.1007/s11248-006-9022-6. 